NOTES ON THE NECKERACEAE (MUSCI) .8.

PENDULOTHECIUM, A NEW GENUS FROM NEW-ZEALAND AND NORFOLK ISLAND

\title{
ENROTH, J
}

1991

ENROTH , J \& He , S 1991, ' NOTES ON THE NECKERACEAE (MUSCI) .8.

PENDULOTHECIUM, A NEW GENUS FROM NEW-ZEALAND AND NORFOLK ISLAND ' , New Zealand journal of botany, vol. 29 , pp. 7-16 .

http://hdl.handle.net/10138/26284

acceptedVersion

Downloaded from Helda, University of Helsinki institutional repository.

This is an electronic reprint of the original article.

This reprint may differ from the original in pagination and typographic detail.

Please cite the original version. 


\section{Notes on the Neckeraceae (Musci) \\ 8. Pendulothecium, a new genus from New Zealand and Norfolk Island}

\author{
JOHANNES ENROTH \\ Department of Botany \\ University of Helsinki \\ Unioninkatu 44 \\ SF-00170 Helsinki, Finland
}

\section{SI HE}

Department of Biological Sciences

University of Cincinnati, Cincinnati, Ohio 45221-0006

USA

\begin{abstract}
Pendulothecium Enroth \& He gen. nov. (Neckeraceae) includes the species $P$. oblongifolium (Hook. f. \& Wils.) Enroth \& He comb. nov., $P$. auriculatum (Wils.) Enroth \& He comb. nov., and $P$. punctatum (Hook. f. \& Wils.) Enroth \& He comb. nov. The first mentioned species has previously been assigned to the genus Porotrichum (Brid.) Hampe and the two latter species to Homalia (Brid.) B.S.G., which is pointed out to be almost exclusively a northern hemisphere genus. Pendulothecium is characterised by a unique combination of features, the most important of which are: the (bi)pinnate, often fairly dense mode of branching; the auriculate, mostly not complanate or spreading leaves; the nontwisted, in wet state $150-170(-250) \mu \mathrm{m}$ thick setae; and the cernuous to pendulous, in wet state broadoblong to ellipsoid capsules. An exclusively Australasian (New Zealand and Norfolk Island) distribution provides further generic distinction. All three species are described and illustrated, and a key to them is provided.
\end{abstract}

Keywords bryology; mosses; taxonomy; Neckeraceac; Homalia; Porotrichum; Pendulothecium gen. nov.; descriptions; illustrations; distribution; New Zealand; Norfolk Island

\section{$B 90042$}

Received 3 September 1990; accepted 16 January 1991

\section{INTRODUCTION}

In the course of studies on the generic taxonomy of the Neckeraceae (senior author) and revision of the genus Homalia (Brid.) B.S.G. (junior author), it became obvious that the mosses currently known as Homalia auriculata Wils. in Hook. f., H. punctata (Hook. f. \& Wils.) Wijk \& Marg., and Porotrichum oblongifolium (Hook. f. \& Wils.) Broth. in Dix. share several peculiar characters of taxonomic significance. These three species form a coherent and distinct group which must be recognised at the generic level. A discussion of the generic distinctions and a comparison with Homalia is provided after the description of the genus.

It should be noted that the Neckeraceae is here defined broadly, as in the previous parts of these "Notes" (Enroth 1990a, b). The Thamnobryaceae (validated by Margadant \& During 1982; see also Buck \& Vitt 1986), which was first segregated from the Neckeraceae by Mönkemeyer (1927, as Thamniaceae nom. illeg.), is a doubtful taxon (cf. Norris \& Enroth 1990) and should probably be included in the latter family. As Ochyra (1986c) noted, "there still are many adherents of the subfamily status of this taxon", including the present authors.

\section{Pendulothecium Enroth \& He, gen. nov.}

Synonym: Homalia (Brid.) B.S.G. subg. Spathularia Broth., Nat. Pflanzenfam. 1(3): 850. 1906; non Spathularia Pers. 1797 (Fungi).

Plantae mediocres vel satrobustae, frondosae, (bi)pinnatim ramosi, non vel leviter nitidae. Stipes valde indistinctus, foliis non differentibus. Folia superiora plerumque auriculata, ad $1.8 \mathrm{~mm}$ longa, laxe vel arte imbricata, ligulata vel late oblonga vel obovate-orbiculata, apicibus acutis vel obtusis vel rotundatis, saepe mucronatis; marginibus ad basim integris vel crenulatis, ad apicem denticulatis vel valde et irregulariter dentatis; costa simplex sed supra saepe bifurcata, valida, longitudine circa $1 / 2 \mathrm{vel}$ usque ad $5 / 6$ folia; cellulae foliorum incrassatae, laeves, 5-7 $\mu \mathrm{m}$ latae, apicales $10-12 \mu \mathrm{m}$ vel usque ad circa $25 \mu \mathrm{m}$ longae, basales usque ad $40 \mu \mathrm{m}$ longae. 
Dioicae. Gametoccia in caulibus secundariis vel interdum in ramis principalibus. Perigonia gemmiformis, $0.5-0.6 \mathrm{~mm}$ alta. Folia interiora perichaetalia usque ad $2.4 \mathrm{~mm}$ longa, ad basim vaginantia, ov ata vel lanceolata, sat abrupte in acumine ligulato vel lanceolato attenuata. Seta 13-14 mm longa, non tortilis, ubi humida 150 $170 \mu \mathrm{m}$ lata sed infra thecam usque ad $250 \mu \mathrm{m}$ lata. Theca cernua vel pendula, circa $1.3 \mathrm{~mm}$ longa, ubi humida late oblonga vel ellipsoidea. Annulus praesens. Operculum late conicum, rostratum. Calyptra cucullata, $1.5 \mathrm{~mm}$ longa. Sporae sublaeves, $16-20 \mu \mathrm{m}$ diametro.

Type species: Pendulothecium auriculatum (Wils.) Enroth \& He (Homalia auriculata Wils. in Hook. f.)

Plants growing in flat mats or tufts, medium-sized to fairly robust, frondose, dark-, yellowish-, brownishor sordid-green, dull or slightly glossy. Primary stems creeping, brittle, in cross-section with small, thick-walled epidermal cells surrounding 2-5 rows of thick-walled cortical cells which grade to larger, thin-walled medullary cells, central strand none. Rhizoids borne in tufts just below the leaf insertion, sparsely branched, smooth, reddish-brown. Leaves of the primary stems c. $0.5 \mathrm{~mm}$ long. Secondary stems (bi)pinnately branched (except in etiolated specimens), incross-section with small, thick-walled epidermal cells surrounding 2-7 layers of cortical cells which often become somewhat larger inwards and grade to larger medullary cells with thinner walls, central strand none. Stipe very poorly defined, stipe leaves not differentiated. Pseudoparaphyllia none; branch primordia covered by foliose embryonic leaves. Axillary hairs 3-5-celled, 1-2 basal cells short and pigmented. Leaves of the secondary stems to $1.8 \mathrm{~mm}$ long, loosely to closely imbricate, more or less concave, decurved and weakly plicate when dry, or undulate, ligulate to broad to broad-oblong to obovate-orbicular, not infrequently widest above midleaf, base usually auricled (sometimes with no auricles), apex acute to obtuse to rounded, often mucronate; margins entire or crenulate below, denticulate to strongly and irregularly dentate above, occasionally entire or nearly so throughout; costa simple but not infrequently bifurcate above, at least the basal part wide, reaching from c. 1/2 to $5 / 6$ the leaf length, in cross-section adaxially flat, abaxially more or less convex, formed of homogeneous, thickwalled cells; leaf cells smooth, incrassate, mostly with solid walls, apical cells from $10-12$ to c. $25 \mu \mathrm{m}$ long and 5-6 $\mu \mathrm{m}$ wide, quadrate or rounded to longrhomboid or long-hexagonal, similar cells usually present in several rows downwardsalong the margins, inner laminal cells and juxtacostal cells at midleaf longer, basal cells oblong or rectangular to nearly linear, to c. $40 \mu \mathrm{m}$ long, 5-7 $\mu \mathrm{m}$ wide, alar cells indistinct.

Dioicous. Perigonia lateral on the secondary stems and (rarely) on the bases of the main branches, gemmiform, 0.5-0.6 $\mathrm{mm}$ high. Perigonial leaves concave, ecostate, broadly ovate, innermost ones abruptly narrowed to a short, lanceolate acumen; margins entire throughout; cells smooth, incrassate, variable in shape, 1-2 marginal rows of regularly rectangular cells usually present. Paraphyses numerous, filiform, at least as long as the antheridia, hyaline except 1-3 basal cells sometimes pigmented. Perichaetia lateral on the secondary stems, more rarely on the bases of the main branches. Inner perichaetial leaves to c. $2.4 \mathrm{~mm}$ long, from a sheathing, ovate or lanceolate base narrowed to a ligulate or lanceolate and mostly spreading acumen; margins entire below, denticulate to strongly and irregularly dentate above; costa absent or rather obscure and short, sometimes strong and reaching near the apex; cells smooth, incrassate, walls of the laminal cells solid or porose throughout, a marginal row of quadrate to rectangular cells usually present from the base of the acumen to (or nearly to) the base of the leaf. Paraphyses numerous, filiform, hyaline, reaching above the archegonia. Vaginula about $1 \mathrm{~mm}$ high, rather wide, greyish-brown below but mouth darker brown, somewhat glossy, bearing numerous paraphyses and archegonia. Seta 13-14 mm long, non-twisted, when wet 150-170 $\mu \mathrm{m}$ diameter for most of its length but thickening to c. $250 \mu \mathrm{m}$ wide just below the capsule, reddish- or orange-brown, smooth. Capsule cernuous to pendulous, 1.3-1.4 $\mathrm{mm}$ long, somewhat asymmetric, broadly oblong to ellipsoid when wet, smooth, light brown; apophysal cells small, incrassate; stomata phaneroporous; exothecial cells slightly collenchymatous, mostly rectangular to penta- or hexagonal and averaging $c$. $50 \mu \mathrm{m}$ long, incrassate below but towards the mouth somewhat shorter and thinner-walled. Annulus distinct, formed of 2-3 rows of relatively thickwalled, angular cells conspicuously longer than the suboral exothecial cells. Peristome double, perfect hypnoid; exostome teeth 16 , lanceolate, not distinctly shouldered, about $550 \mu \mathrm{m}$ high, dorsally densely cross-striolate from the base to c. $3 / 5$ the tooth length, apex papillose, median line zig-zag, ventrally with strongly projecting trabeculae; basal membrane about $250 \mu \mathrm{m}$ high, finely papillose; endostome segments lanceolate, keeled, widely gaping, finely papillose, apex subulate and knotted; cilia mostly in groups of 3, well-developed, knotted-appendiculate. Operculum broadly conic-rostrate, $1 \mathrm{~mm}$ high, 
smooth, brown, cells near the base incrassate, mostly hexagonal and rather isodiametric, above becoming longer and rectangular with thinner walls. Calyptra cucullate, $1.5 \mathrm{~mm}$ high, smooth, light-brown below but apically dark brown, cells incrassate, walls solid below, upper cells more narrow-elongate with strongly porose walls. Spores yellowish, nearly smooth, 16-20 $\mu \mathrm{m}$ diameter.

Brotherus (1906) established the subgenus Spathularia Broth. of Homalia for the species $H$. auriculata, $H$. pulchella $(=H$. punctata), and $H$. oblongifolia (Hook. f. \& Wils.) Wils. in Hook. f. and retained the subgenus in the second edition of "Die natürlichen Pflanzenfamilien" (Brotherus 1925). However, slightly later (in Dixon 1927) he transferred H. oblongifolia to the genus Porotrichum (Brid.) Hampe, but, as will be discussed below, on untenable grounds.

Since all species of Pendulothecium Enroth \& He have previously been placed in Homalia, a comparison of the two genera is appropriate (Table 1). The combination of characters presented in Table 1 for Pendulothecium relative to Homalia serves to distinguish it from all other genera of the Neckeraceae as well.

The almost exclusively northern hemisphere distribution of Homalia becomes clear after the segregation of the genus described here and because H. falcifolia (Hook. f. \& Wils.) Wils. in Hook. f. actually belongs to the Plagiotheciaceae, possibly to the recently described genus Pseudotaxiphyllum Iwats. (Iwatsuki 1987). The African and Indian Homalia pygmaea Broth., on the other hand, evidently represents the genus Symphyodon Mont.

Table 1 Comparison of Pendulothecium Enroth \& He with Homalia (Brid.) B.S.G.

\begin{tabular}{|c|c|c|}
\hline & Pendulothecium & Homalia \\
\hline Habit & $\begin{array}{l}\text { Plants frondose, } \\
\text { not to slightly glossy }\end{array}$ & $\begin{array}{l}\text { Plants not frondose, } \\
\text { strongly glossy }\end{array}$ \\
\hline Branching & $\begin{array}{l}\text { (Bi)pinnate, fairly } \\
\text { dense }\end{array}$ & Irregular, remote \\
\hline Leaves & $\begin{array}{l}\text { Mostly not complanate } \\
\text { or spreading, auricled }\end{array}$ & $\begin{array}{l}\text { Complanate-spreading, } \\
\text { not auricled }\end{array}$ \\
\hline Seta & $\begin{array}{l}150-170(-250) \mu \mathrm{m} \text { thick } \\
\text { when wet, non-twisted }\end{array}$ & $\begin{array}{l}\text { c. } 120 \mu \mathrm{m} \text { thick when } \\
\text { wet, twisted }\end{array}$ \\
\hline Capsule & $\begin{array}{l}\text { Cemuous to pendulous, } \\
\text { broadly oblong to } \\
\text { ellipsoid when wet }\end{array}$ & $\begin{array}{l}\text { Erect to suberect, } \\
\text { cylindric to oblong } \\
\text { when wet }\end{array}$ \\
\hline Operculum & $\begin{array}{l}\text { Broadly conic- } \\
\text { rostrate }\end{array}$ & $\begin{array}{l}\text { Narrowly conic- } \\
\text { rostrate }\end{array}$ \\
\hline Range & $\begin{array}{l}\text { New Zealand, } \\
\text { Norfolk Island }\end{array}$ & $\begin{array}{l}\text { Mainly northem } \\
\text { hemisphere }\end{array}$ \\
\hline
\end{tabular}

of the Symphyodontaceae. (The taxonomic positions of Homalia falcifolia and $H$. pygmae $a$ will be dealt with in a forthcoming paper by the junior author). Hence, the only species of Homalia which crosses the equator is the neotropical $H$. defoliata (C. Müll.) Jaeg., of which the junior author has seen specimens from as far south as Rio de Janeiro, Brazil.

Gametophytically, the regularly pinnate or bipinnate mode of branching and especially the auriculate leaves of Pendulothecium are unique among those genera of the Neckeraceae with perfect hypnoid peristomes. In addition to Homalia, these include Limbella (C. Müll.) Broth. (Ochyra 1987), Thamnobryum Nieuwl.,Porothamnium Fleisch., and the recently described Bryolawtonia Norris \& Enroth (Norris \& Enroth 1990). The sporophytes of the genera Handeliobryum Broth. (Ochyra 1986a) and Touwia Ochyra (Ochyra 1986b) are unknown, but their gametophytic characters suggest that they may belong to this group, too. Limbella, Thamnobryum, Porothamnium, and Handeliobryumare rather robust plants with a distinct stipe, well-differentiated stipe leaves and a central strand in the stem, except in Thamnobryum subg. Parathamnium (Fleisch.) Ochyra, which comprises two aquatic species with at least partly limbate, of ten elliptic leaves (Ochyra 1990). The monotypic Bryolawtonia, which is endemic to North America, resembles Pendulothecium in that it lacks both a well-defined stipe with differentiated leaves and a central strand. However, the former branches quite irregularly and has a completely different leaf shape and areolation; also its capsule is inclined rather than cernuous or pendulous, and the operculum is conic instead of conic-rostrate as in Pendulothecium. The small Australian Touwia with its irregular branching, 0.5$0.65 \mathrm{~mm}$ long, mostly lanceolate or oblong-lanceolate leaves, and a very strong costa, shows no gametophytic resemblance to Pendulothecium.

The sporophytes of all species of Pendulothecium are completely similar and highly diagnostic at the generic level. Especially characteristic is the entirely non-twisted seta which, in wet state, is $150-170 \mu \mathrm{m}$ diameter but flares to c. $250 \mu \mathrm{m}$ diameter below the cernuous or pendulous, broadly oblong to ellipsoid capsule (Fig. 1D). When dry, the capsules exhibit quite variable shapes; some are oblong or ellipsoid but others may be rather narrow and distinctly constricted below the mouth (Fig. 1E-G). We suggest that the perfect hypnoid peristome, the attitude and shape of the capsule, and the seta characters of Pendulothecium represent plesiomorphic states within the Neckeraceae. In broad terms, the 
evolutionary tendencies in the morphology of the neckeraceous mosses reflect a shift from a mainly terricolous or saxicolous existence in the primitive forms (with perfect hypnoid peristomes) to a mainly epiphytic one in the more advanced taxa (with more or less reduced peristomes).

A note on pseudoparaphyllia may be pertinent here. The formal generic description above makes a distinction between true pseudoparaphyllia and the embryonic leaves which often enclose the branch primordia of mosses. Some bryologists define as pseudoparaphyllia all "appendages" which shelter the branch primordia, regardless of their exact place of insertion. We feel, however, that small foliose structures which are inserted at the edges of branch primordia should be regarded as and termed "embryonic leaves". True pseudoparaphyllia, then, arise from the stem and are placed close to branch primordia, but not inserted directly at their edges. We do not insist that the distinction between embryonic leaves and true pseudoparaphyllia is always clear and absolute; rather, we wish to point out that this problem exists and is worth further scrutiny.

\section{Key to the species of Pendulothecium}

1 Leaves irregularly undulate; costa reaching in the secondary stem leaves and branch leaves $4 / 5-5 / 6$ the leaf length Pendulothecium oblongifolium Leaves not undulate or rarely with $1(-2)$ lunate undulation(s); costa reaching in the secondary stem leaves and branch leaves about $1 / 2$ the leaf length

2 Leaves of the secondary stems to $1.1 \mathrm{~mm}$ long, base indistinctly or not at all auricled; leaf margin strongly and irregularly dentate above; apical leaf cells mostly $10-12 \mu \mathrm{m}$ long.... Pendulothecium punctatum Leaves of the secondary stems to $1.8 \mathrm{~mm}$ long, base distinctly auricled; leaf margin denticulate or nearly entire above; apical leaf cells to c. $25 \mu \mathrm{m}$ long

\section{Pendulothecium auriculatum}

Pendulothecium oblongifolium (Hook. f. \& Wils.) Enroth \& He, comb. nov. Fig. 1 Hookeria punctata Hook.f.\& Wils. var.oblongifolia Hook. f. \& Wils., London J. Bot. 3: 550. 1844. Lectotype (designated here): New Zealand. Bay of Islands (BM!).

Homalia oblongifolia (Hook. f. \& Wils.) Wils. in Hook. f., Fl. Nov. Zel. 2: 115.91 f. 6. 1854.

Porotrichumoblongifolium (Hook.f.\&Wils.) Broth. in Dix., New Zealand Inst. Bull. 3(5): 268. 1927.

Plants growing in flat mats or tufts, medium-sized, frondose, dark-green to sordid-green, dull. Primary stems with 3-5 layers of cortical cells which become somewhat larger inwards and grade to distinctly larger medullary cells with relatively thin walls. Leaves of the primary stems ligulate (-spathulate); leaf margins entire below, strongly and irregularly toothed above; costa simple, strong, reaching approximately $2 / 3$ the leaf length; leaf cells smooth, incrassate, near apex rhomboid to oval or irregular, isodiametric, to c. $12 \times 6 \mu \mathrm{m}$, median cells rather more rectangular and somewhat longer, basal cells rectangular to oblong, to $25 \mu \mathrm{m}$ long, $5-6 \mu \mathrm{m}$ wide, marginal cells in 1-3 rows mosuly quadrate, shorter than inner laminal cells. Secondary stems with cortical cells mostly 5-7 layered, becoming larger inwards and grading to distinctly larger medullary cells with relatively thin walls. Leaves of the secondary stems crowded, loosely imbricate, irregularly undulate, erecto-patent when dry, patent when wet, to $1.5 \mathrm{~mm}$ long, ligulate (-spathulate) from a much widened, auricled base, apex obtuse-mucronate to acute; leaf margins undulate, entire or crenulate below, upwards becoming first slightly and then strongly and irregularly dentate/crenate; costa strong, reaching 4/5-5/6 the leaf length; leaf cells at apex, midleaf and in several rows downwards along the margins quadrate to rounded and 5-7 (-8) $\mu \mathrm{m}$ in diameter, or rhomboid-oval and to c. $12 \mu \mathrm{m}$ long and $6 \mu \mathrm{m}$ wide, juxtacostal cells in a few rows slightly or distinctly longer, basal cells rectangular or oblong, to c. $30 \times$ 5-7 $\mu \mathrm{m}$. Flagelliform, microphyllous branches sometimes produced; their leaves to $c .0 .25 \mathrm{~mm}$ long, (ovate-)lanceolate to spathulate, apex acute; leaf margins serrulate to serrate; costa simple, reaching $1 / 2$ the leaf length or slightly more; leaf cells smooth, with distinctly thinner walls than the cells of the leaves of the secondary stems and 


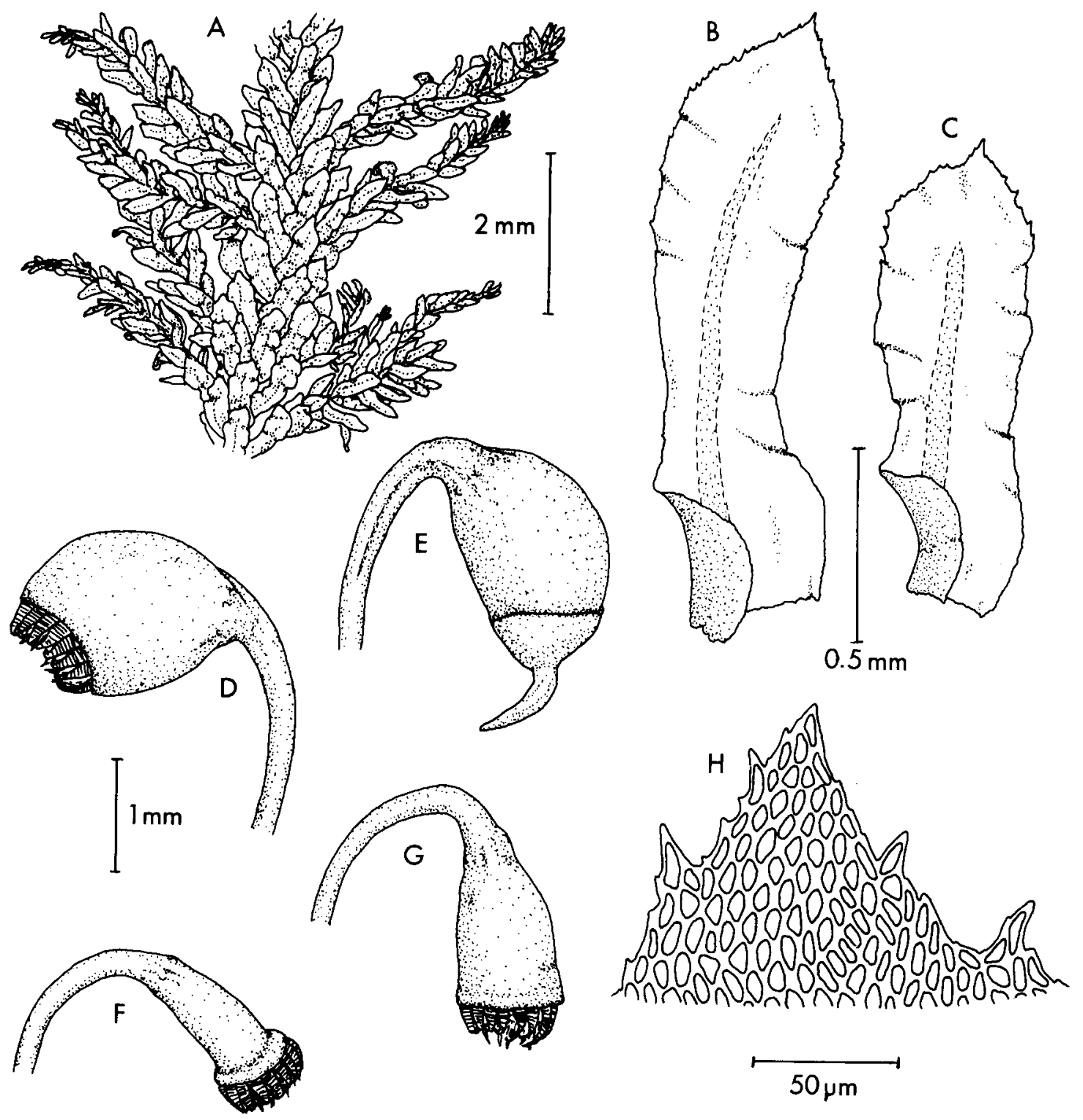

Fig. 1 Pendulothecium oblongifolium (Hook. f. \& Wils.) Enroth \& He: A, portion of plant; B, stem leaf; C, branch leaf; D, wet capsule; E-G, dry capsules; H, leaf apex. (A, B and F-H from Cheeseman s.n.- WELT M19319, C-E from Auckland, Knight s. n. - H-SOL).

branches, irregularly angular, mostly $10-12 \times 6-$ $8 \mu \mathrm{m}$.

Perigonia lateral on the secondary stems. Perichaetia lateral on the secondary stems and the bases of the main branches. Innerperichaetial leaves 2.2-2.4 mm long, base sheathing, (ovate-) lanceolate, rather abruptly narrowed to a ligulate (-spathulate) acumen; costa simple, fairly strong, vanishing below apex; margins entire near base, a few long and sharp teeth are present at the apex; walls of the leaf cells solid throughout, the marginal row of quadrate to rectangular cells often more or less discontinous.

Homalia oblongifolia was transferred to the genus Porotrichum by Brotherus in Dixon (1927). Dixon, 
as well as Sainsbury (1955), regarded the resemblance of $P$. oblongifolium to Homalia pulchella $(=H$. punctata) as only superficial and not indicative of a close relationship. However, Sainsbury retained the plant in Porotrichum with reservations: "I have left the plant in this genus, but am very doubtful as to whether it should be there". He stressed that the "fruiting characters" resemble Homalia rather than Porotrichum, but that the vegetative features point to the latter genus. In our opinion, the perfect hypnoid peristome of Pendulotheciumoblongifolium (Hook. f. \& Wils.) Enroth \& He without question precludes it from Porotrichum (cf. Norris \& Enroth 1990). Furthermore, the (bi)pinnate mode of branching; the lack of a central strand in the stem; the very poorly defined stipe with non-differentiated stipe leaves; and the auricled, undulate leaves (Fig. 1B,C) are not at all in accordance with that genus.

The (bi)pinnate branching is distinct in all welldeveloped specimens, but there are very etiolated, small and sparsely branched specimens (such as Martin 565 from Picton, Marlborough, deposited in CHR).

Pendulothecium oblongifolium is endemic to New Zealand, and evidently more common in the North Island. Martin (1958) included it in the mosses notencountered south of $41^{\circ} 30^{\prime} \mathrm{S}$. This seems roughly to hold true, although one collection from Westland comes from $42^{\circ} 42^{\prime} \mathrm{S}$ (see below). The species grows on roots, rocks and soil, preferably in damp, shady places.

Selected specimens examined:

NEW ZEALAND. "Nova Zeelandia", 1867, Knight 227 (BM). North Island: Without exact locality, Knights.n.(H-SOL). NorthAuckland Land District. Waitakere Ranges, on roots of trees, IX. 1882, Cheeseman s. n. (WELT M19319, "ex herb. T. F. Cheeseman No. 111"); Great Barrier Island, road from Tryphena to Claris, outer Hauraki Gulf, $120 \mathrm{~m}$, on top surface of large exposed root of Vitex lucens in taraire/puriri/kohekohe forest, 6. I. 1984, Beever 22-21 (CHR 405937). South Auckland Land District. Hamilton, "Claudelands, Waikato", $300 \mathrm{ft}$, kahikatea bush, on bark, 1. VII. 1938, Poole 20 (WELT M19311, CHR "Herbarium of G.O.K. Sainsbury No.4341"); Peria Reserve, near Matamata, Waikato, on roots in shady bush, 29. XII. 1946, Sainsbury s. n.(WELTM19316).Taranaki LandDistrict. Without exact locality, II. 1913, Heywood s. n. (WELT M19321). Hawkes Bay Land District. Near Wairoa, Makeretu stream, $1 / 4$ mile below the falls, in bush on earth, 26. XII. 1932, Hodgson s. n. (CHR, "The K. W. Allison Collection No. 3129"). Wellington Land
District. Wilton's Bush, on road, 12. VII. 1939, Mason s. n. (WELT M19312); Eastbourne, damp situation on forest floor, on stone, 4.IV. 1950,Butler 2687 (CHR, "The K. W. Allison Collection No. 3636"). South Island: Marlborough Land District. Picton, Grove Track, on stones by stream in forest, V. 1944, Martin 564 (WELT M19318); Swingbridge Track, Pelorus Ridge Scenic Reserve, $200 \mathrm{ft}$, stream underkamahi in Nothofagus solandri forest, epiphyte on woody root underMelicytus, 1. X. 1983,Brownsey s. n. (WELT M6967). Nelson Land District. West Haven, west coast, end of road at Pakawa Gorge, low elevation, "early 1935", Simpson \& Thompson s. $n$. (WELT 19325, CHR 217867). Westland Land District. Four Mile Creek, 17. V. 1977, Bartlett 19092 (WELT M8478).

Pendulothecium punctatum (Hook. f. \& Wils.) Enroth \& He, comb. nov. Fig. 2 Hookeria punctata Hook. f. \& Wils., London J. Bot. 3: 550. 1844. Lectotype (designated here): New Zealand. Bay of Islands, Hooker 379 (BM!, two isolectotypes $\mathrm{BM}$ !).

Homalia punctata (Hook. f. \& Wils.) Wijk \& Marg., Taxon 9: 51. 1960.

Homalia pulchella Wils. in Hook. f., Fl. Nov. Zel. 2: 114. 91 f. 5. 1854, nom. illeg. incl. spec. prior. (Hookeria punctata Hook. f. \& Wils., 1844).

Plants medium-sized, dark-green to sordid-green, dull. Primary stems in cross-section with mostly 2 rows of cortical cells which are rather sharply demarcated from the much larger, thin-walled medullary cells. Leaves of the primary stems broadoblong or obovate, apices obtuse or nearly rounded; margins entire below, denticulate above; costa simple, wide at base but fairly obscure, vanishing below midleaf; leaf cells at apex and in several rows downwards along the margins mostly rhomboid or oval, c. $10 \times 5-6 \mu \mathrm{m}$, inner laminal cells at midleaf longer, mostly long-rhomboid, basal cells oblong or rectangular, to c. $25 \mu \mathrm{m}$ long, 5-6 $\mathrm{mm}$ wide. Cortical cells of the secondary stems 2(-3) layered, becoming somewhat larger inwards and grading to still larger, thin-walled medullary cells. Leaves of the secondary stems to c. $1.1 \mathrm{~mm}$ long, closely imbricate, frequently decurved and concave (branch leaves sometimes more or less complanate and spreading), weakly plicate when dry, asymmetric, broad-oblong or obovate (-spathulate) from a narrowed, indistinctly auricled base (auricle sometimes absent), apex broadobtuse to rounded, often mucronate; margins entire below, fairly strongly and irregularly dentate/crenate 


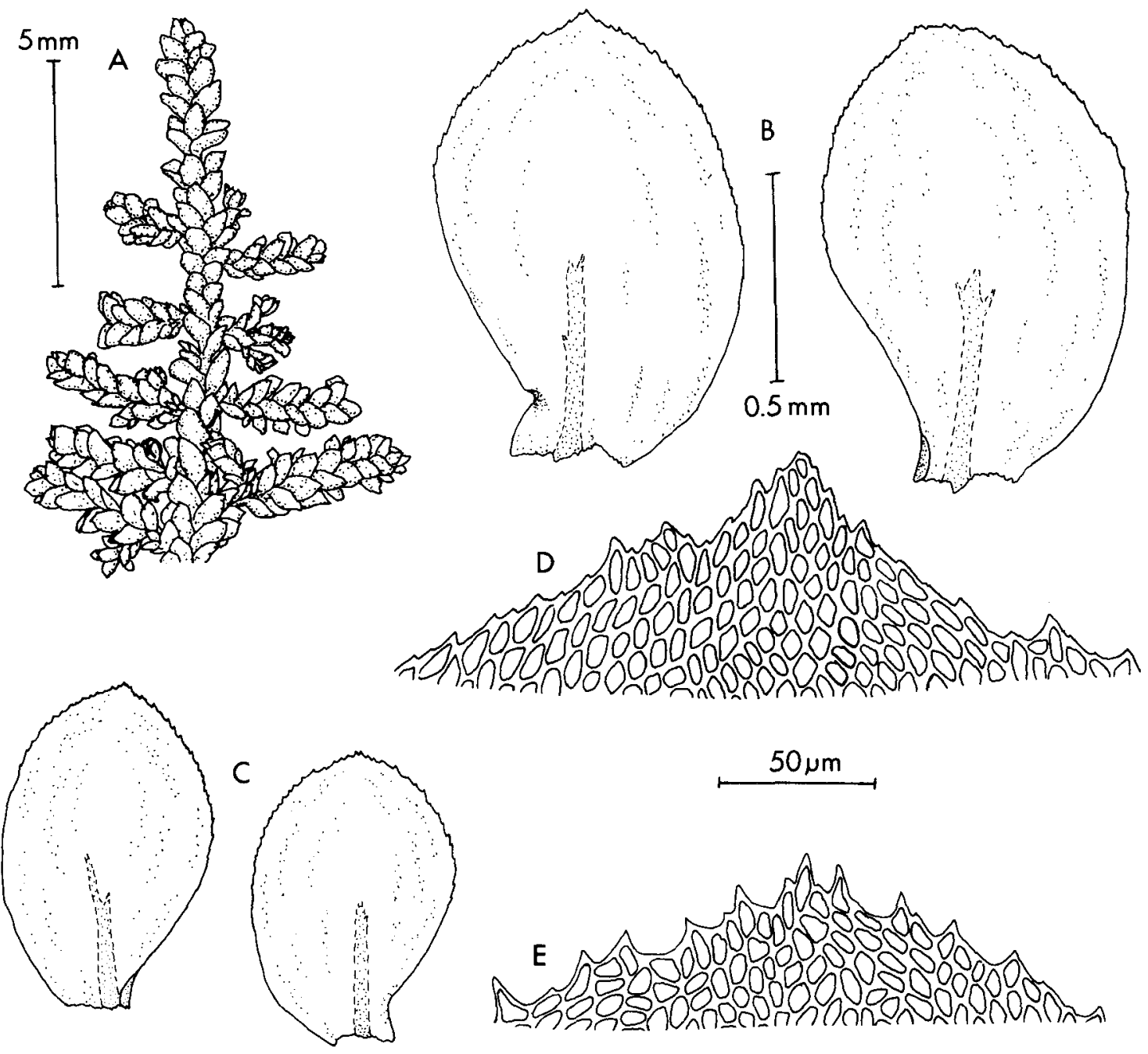

Fig. 2 Pendulothecium punctatum (Hook. f. \& Wils.) Enroth \& He: A, upper portion of plant; B, stem leaves; C, branch leaves; D, E, leaf apices. (From Beever 46-44 - WELT M10627).

above; costa reaching to about $1 / 2$ the leaf length; leaf cells in apex and downwards along the margins in several rows mostly rhomboid or oval, $10-12 \times$ 5-6 $\mu \mathrm{m}$, inner laminal cells at midleaf longer, oblong or long-rhomboid, juxtacostal basal cells oblong or rectangular to nearly linear, toc. $40 \times 5-6 \mu \mathrm{m}$. Branch tips sometimes flagelliform and microphyllous.

Perichaetia lateral on the secondary stems. Inner perichaetial leaves to $1.1 \mathrm{~mm}$ long, ecostate or with an obscure and short costa, from a sheathing, ovate base rather abruptly narrowed to a ligulate or lanceolate, curved acumen; margins entire below, strongly and irregularly dentate in the upper part of the acumen; laminal cells with solid walls throughout. We do not agree with Sainsbury's (1955) notion that the resemblance of Homalia punctata to $H$. oblongifolia is superficial. In addition to having identical sporophytes, these species share a dull aspect; a pinnate to bipinnate mode of branching; strongly and irregularly dentate/crenate upper leaf margins (also in the perichaetial leaves); and short apical leaf cells (Fig. 2D, E).

Branch leaves of Pendulothecium punctatum (Hook.f.\& Wils.) Enroth \& He are sometimes rather complanate which, along with the very flat mats or tufts, may give an impression of Homalia. Sainsbury 
(1955) described the leaf orientation as "distichous". Our observations indicate this to be incorrect; quite often the complanate condition is not pronounced (Fig. 2A). The auricles are not very distinct (Fig. 2B, C), and apparently all specimens have some completely non-auriculate leaves. The branching of Homalia punctata (as H. pulchella) was desribed as "freely pinnate" or "subpinnate" by Sainsbury (1955) but, more often than not, the branching is just as distinctly pinnate as in the two other species.

Pendulothecium punctatum grows in similar habitats and on similar substrates as $P$. oblongifolium, with which it is rather frequently found in association. It occurs in both main islands of New Zealand as well as on Stewart Island and is also known from Norfolk Island (Dixon 1927; Sainsbury 1955; Streimann \& Curnow 1989). Dixon (1927) doubted the correctness of the records from Tasmania; according to Sainsbury (1955), it does not occur there. Scott et al. (1976) cited the name Homalia punctata in their book dealing with the mosses of southern Australia, but failed to indicate the State from which it was recorded. Streimann \& Curnow (1989) included Tasmania in its distribution area, but their record was based on previous literature $(\mathrm{H}$. Streimann pers. comm.). We have not seen any specimens from Tasmania.

\section{Selected specimens examined:}

NEW ZEALAND. North Island: South Auckland Land District. Lower Waikato, X. 1895, Petrie s. $n$. (WELT M865); Between Lake Rotoehu and the coast of Bay of Plenty, $400 \mathrm{ft}$, VI. 1941, Allison s. $n$. (WELT M860); 14 km E of Kawhia, Te Kauri Scenic Reserve, Devlin Track, $100 \mathrm{~m}$, on horizontal branch of Melicytus ramiflorus in mixed broadleaf forest in wet gully with Elatostema, 27. X. 1989, Brownsey s. n. (WELT M27062). Taranaki Land District. New Plymouth ("Plymouth"), 1898, Thomson s. n. (BM); Stratford, King Edward Memorial Park, IX. 1946, Martins. n. (CHR 243433). Wellington Land District. Without locality or collector (H-BR, "Herb. W. Bell"); North of Wellington, Kay Conservation Covenant, Pukerua Bay (100 Acre Bush), on soil and roots along stream in Dysoxylum spectabile forest, 5. VIII. 1989, Polly s. n. (WELT M26874). Gisborne Land District. Near Gisborne, Gray's Bush, on rocks, 27. XII. 1949, Sainsbury s. n. (WELT M17156); Southern Poverty Bay, Maraetaha, on roots etc. in light bush, 19. XII. 1953, Sainsbury s. n. (WELT M17158). Hawkes Bay Land District. Dannevirke, "Humile Creek", among Hookeria, Colenso a. 1171 (WELT 4012); Near Waipukurau, on root in light bush in gully, 4. III. 1943, Sainsburys. n. (WELT 17155). South Island: Marlborough LandDistrict. Marlborough,McMahons.n.(WELT 17147).Nelson Land District. D'Urville Island, E side of Kupe Bay, $160 \mathrm{~m}$, on stones on floor of matute kohekohe forest, 17.I. 1988,Brownseys.n.(WELTM10211); Anatoki River side gully, $610 \mathrm{~m}$, on rocks in waterfall, 25 . I. 1987, Glennys.n. (WELTM9167). Canterbury Land District. Mount Peel, Beckett s. n. (WELT M3847, "Herb. J. H. McMahon"). Westland Land District. Otira, on bank beside pipeline, I. 1943, Martin s. $n$. (WELT M17142). Otago Land District. Otago Peninsula, Mt. Charles, $1200 \mathrm{ft}$, on tree roots in damp gully in bush, 22. VII. 1970, Child 1720 (BM); Dunedin, Fraser's Gully, $400 \mathrm{ft}$, on rock in shady bush, assoc. Homalia falcifolia, Cyathoporum bulbosum, Echinodium hispidum, 20.X. 1970,Child 2256 (BM). Southland Land District. 20 miles NW of Riverton, $500 \mathrm{ft}$, in damp, open bush, assoc. Homalia, Porella, Lophocolea, 2. XI. 1972, Child 1590 (BM). Stewart Island. Port William, on tree base, 16. II. 1947, Martin 263.8 (CHR 243435). NORFOLK ISLAND. Without further information, Müller s. n. (BM, "herb. Hampe 1881"); "With Racopilum", Thompson s. n. (BM).

Pendulothecium auriculatum (Wils.) Enroth \& He, comb. nov. Fig. 3 Homalia auriculata Wils. in Hook. f., Fl. Nov. Zel. 2: $115.92 f .4$. 1854. Lectotype (designated here): New Zealand. Without locality, Knight 77(BM!, two isolectotypes BM!).

Plants medium-sized to robust, yellowish-green or brownish-green, slightly glossy. Primary stems in cross-section with 3-5 layers of thick-walled cortical cells which become larger inwards and grade to distinctly larger medullary cells with relatively thin walls. Leaves of the primary stems mostly ligulate (-spathulate) with acute to obtuse apices; leaf margins entire below, dentate above; costa reaching $1 / 3$ the leaf length at most; leaf cells at apex rhomboid to oval or irregular, c. $12 \times 5-6 \mu \mathrm{m}$, median cells longer, long-rhomboid or oblong to nearly rectangular, basal cells mostly rectangular to oblong, to about $25 \mu \mathrm{m}$ long, 5-6 $\mu \mathrm{m}$ wide, marginal cells in a few rows somewhat shorter than the inner laminal cells. Secondary stems relatively rigid, cortical cells 5-7 layered, becoming larger inwards and grading to distinctly larger medullary cells with thinner walls; new secondary stems sometimes innovating from previous year's growth. Leaves of the secondary stems to about $1.8 \mathrm{~mm}$ long, closely imbricate, 


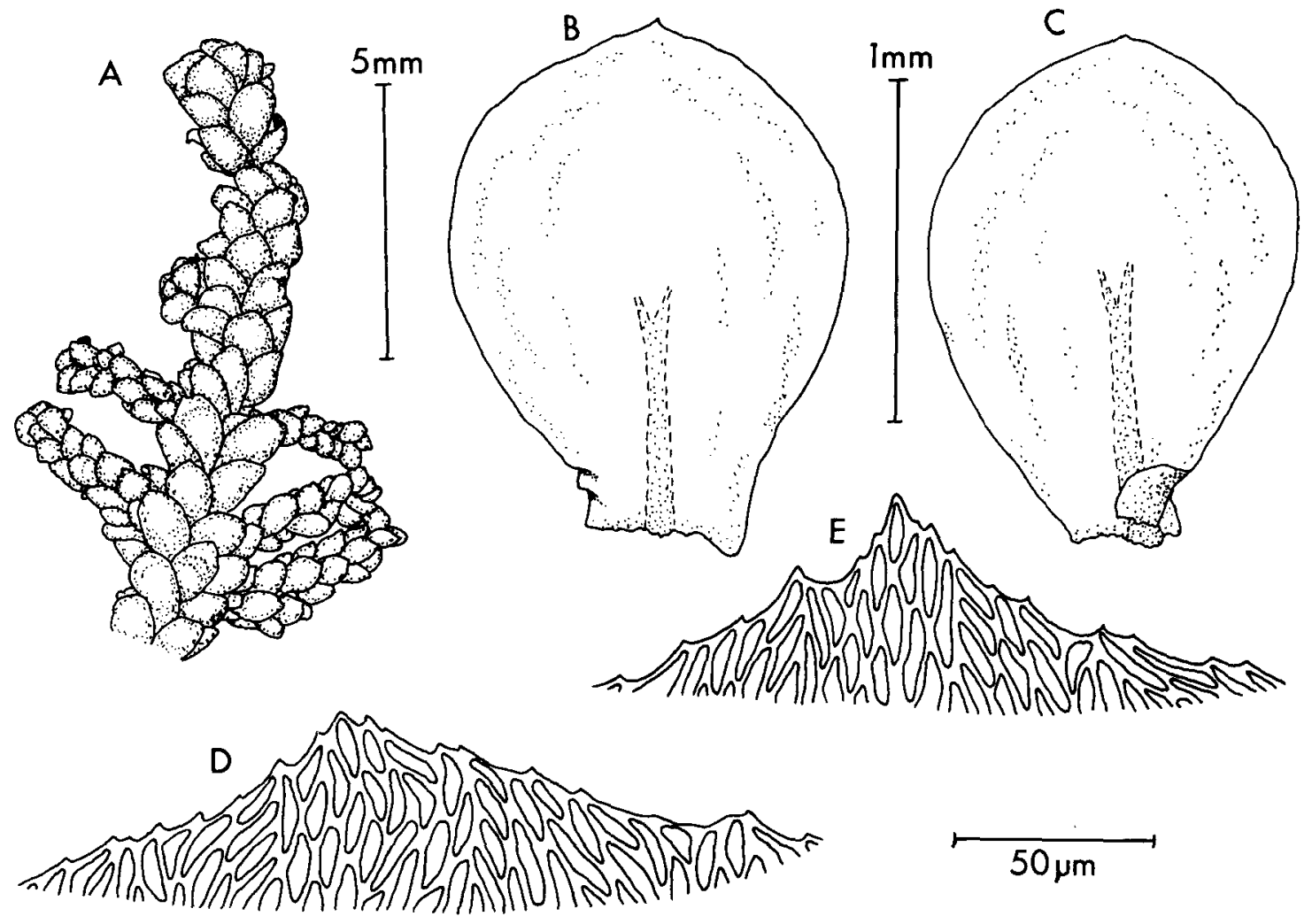

Fig.3 Pendulotheciumauriculatum (Wils.) Enroth \& He: A, upper portion of plant; B, C, stem leaves; D, E, leaf apices. (From Auckland, Knight s. n. - H-SOL).

decurved and more or less concave, often weakly plicate when dry, sometimes with 1(-2) lunate undulation(s), obovate-orbicular from a narrow, auricled base, apex rounded and often mucronate; leaf margins sometimes entire or nearly so throughout but more often denticulate to dentate above; costa reaching c. 1/2 the leaf length; leaf cells near apex mostly long-rhomboid or long-hexagonal to oblong, to c. $25 \mu \mathrm{m}$ long, $5-6 \mu \mathrm{m}$ wide, in midleaf especially near costa somewhat longer, juxtacostal basal cells narrow-rectangular or linear, to about $40 \mu \mathrm{m}$ long with very thick, porose walls, marginal cells from about half the leaf length to base in several rows rhomboid or oval, shorter than the inner laminal cells.

Perichaetia lateral on the secondary stems. Inner perichaetial leaves ecostate or with an obscure, short costa, to about $2.0 \mathrm{~mm}$ long, base sheathing, ovate, rather abruptly narrowed to a lanceolate and spreading acumen; margins entire below, mostly denticulate to dentate near apex; laminal cells with porose walls throughout.
The decurved, often concave leaves of Pendulotheciumauriculatum (Wils.) Enroth \& He superficially resemble those of $P$. punctatum. However, it differs from that species and $P$. oblongifolium by the slightly glossy aspect; the denticulate rather than dentate upper leaf margins; the relatively long (to c. $25 \mu \mathrm{m}$ ) apical leaf cells (Fig. 3D, E); and the porose walls of the laminal cells of the perichaetial leaves. Undulate leaves can not be regarded as characteristic of $P$. auriculatum, but all specimens possess some leaves with one oroccasionally two distinctlunate undulations.

Like the two other species, Pendulothecium auriculatum thrives in moist habitats, where it may grow on soil, rocks, or wood. According to Martin (1958), in the South Island it is restricted to areas with an average annual rainfall in excess of $125 \mathrm{~cm}$. It is endemic to New Zealand, but quite uncommon; Sainsbury (1955) regarded it as "very rare". It was recorded from Australia by Martin (1949), but Streimann \& Curnow (1989) stated that it is "not an Australian moss". 
Selected specimens examined:

NEW ZEALAND. North Island: North Auckland LandDistrict. Withoutlocality, Knights.n. (H-SOL); Waipoua Forest, damp bank in forest, on rocks, 16. V. 1944, Allison 789 (WELT 9992); Te Paki Trig Bush, on damp clay soils, 13. III. 1976, Bartlett 11219 (WELT M 8418). South Island: Westland Land District. Kelly's Hill, on log in upper bush level, 1100m, I. 1943, Martin 25 (WELT9991, "First finding in South Island"); Kumara, on damp clay soils, 23. XII. 1978, Bartlett 14216 (WELT M8419).

\section{ACKNOWLEDGMENTS}

We thank the Curators of BM, CHR, GL, and WELT for the loan of specimens, and Mr. Heinar Streimann (CBG) for information regardingPendulotheciumpunctatum. The constructive comments which Prof. Timo Koponen (Helsinki), Prof. Daniel H. Norris (Arcata), Dr. Ryszard Ochyra (Krákow), and an anonymous referee made on the manuscript are gratefully acknowledged. The work was financially supported by the Emil Aaltonen Foundation (Tampere, Finland), the Academy of Finland, and the University of Cincinnati (Ohio, USA).

\section{REFERENCES}

Brotherus, V. F. 1906: Neckeraceae. IX. Neckereac. In: Engler, A.; Prantl, K., ed., Die natürlichen Pflanzenfamilien 1(3): 835-851. Leipzig, W. Engelmann.

1925: Neckeraceac. In: Engler, A.; Prantl, K., ed., Die natürlichen Pflanzenfamilien ed. 2, 11: 178-202. Leipzig, W. Engelmann.

Buck, W. R.; Vitt, D. H. 1986: Suggestions for a new familial classification of pleurocarpous mosses. Taxon 35: 21-60.

Dixon, H. N. 1927: Studies in the bryology of New Zealand, with special reference to the herbarium of Robert Brown. V. New Zealand Institute bulletin 3: 239-298.

Enroth, J. 1990a: Notes on the Neckeraceae (Musci). 1-2. Neckeropsis calcutensis comb. nov. and the first record of Pinnatellaintralimbal a from New Guinea. Acta Bryolichenologica Asiatica I (in press).

1990b: Notes on the Neckeraceae (Musci). 3-7. Homaliodendron piniforme comb. nov. and new synonymy in Porotrichum, Himantocladium and Neolindbergia. Nova Hedwigia 51: 551-559.
Iwatsuki, Z. 1987: Notes on Isopterygium Mitt. (Plagiotheciaceac). Journal of the Hattori Botanical Laboratory 63: 445-451.

Margadant, W. D.; During, H. 1982: Beknopte flora van Nederlandse blad- en levermossen. Zupthen, Koninklijke Nederlandse Natuurhistorische Vereigning.

Martin, W. 1949: Distribution of mosses indigenous to New Zealand. Transactions and proceedings of the Royal Society of New Zealand 77: 355360.

1958: Survey of moss distribution in New Zealand. The bryologist 61: 105-115.

Mönkemeyer, W. 1927: Die Laubmoose Europas IV. In: L. Rabenhorst's Kryptogamen-flora von Deutschland,Österreich und der Schweiz.Leipzig, Akademische Verlagsgesellschaft.

Norris, D. H.; Enroth, J. 1990: Description of Bryolawtonia Norris \& Enroth (Thamnobryaceae), with observations on the genus Bestia. The bryologist 93: 328-331.

Ochyra, R. 1986a: A taxonomic study of the genus Handeliobryum Broth. (Musci, Thamnobryaceae). Journal of the Hattori Botanical Laboratory 61: 65-74.

1986b: Touwia laticostata, a remarkable new genus and species of moss from Queensland, Australia. Journal of bryology 14: 103-108.

1986c: Neckeraceae Schimp. subfam. Thamnobryoideae (Marg. \& During) Ochyra, stat. nov. Journal of bryology 14: 180-181.

1987: On the taxonomy and family placement of the moss genus Limbella (C. Müll.) Broth. Journal of bryology 14: 465-485.

1990: On the relationships of Thamnobryum negrosense (Bartr.) Iwats. \& Tan (Musci: Thamnobryaceae). Journal of the Hattori Botanical Laboratory 68: 293-302.

Sainsbury, G.O.K. 1955: A handbook of the New Zealand mosses. Royal Society of New Zealand bulletin 5: $1-490$.

Scott, G. A. M.; Stone, I. G.; Rosser, C. 1976: The mosses of southern Australia. London, Academic Press.

Streimann, H.; Curnow, J.; 1989: Catalogue of mosses of Australia and its external territories. Australian Floraand FaunaSeries 10: I-VIII, 1-479. Canberra, Australian Government Publishing Service. 